\title{
Utilization of Natural Materials to Increase Calculation Ability of 4-5 Year-old Children
}

\author{
Henny, La Jeti \\ Early Childhood Education Study Program \\ Muhammadiyah Buton University \\ Baubau, Indonesia \\ heni88buton@gmail.com
}

\begin{abstract}
The purpose of this study is to know the increase in counting ability through the use of nature material of grade A Kindergarten students. The population in this study consisted of 15 students of grade A at Kartika Wirabuana 51 Kindergarten, Baubau. This study used Action Classroom Research method according to Kemmis and Mc. Taggart consisting of four steps: 1 . planning, 2. action, 3. observation, and 4. reflection. The data was collected by field notes, documentation, and observation. The data were analyzed by a descriptive qualitative and quantitative method. The result of this study shows that counting by using the natural material could increase the counting ability of grade A Kindergarten students. The results of this study also show that based on the percentage of students capability before the intervention until the end of the intervention. The preliminary data on students' numeracy skills showed around $45,83 \%$, and after using natural materials in learning, students' numeracy skills increased in each cycle (in the first cycle was $76.33 \%$ and in the second cycle $\mathbf{9 0 . 8 3 \%}$ ). The increase of students counting ability at grade $A$ Kindergarten students by using natural material consists of arranging the number, counting of things, more and less concept, number concept and additional concept.
\end{abstract}

Keywords - Counting ability, Natural material

\section{INTRODUCTION}

According to Law No. 20 of 2003 concerning the National Education System article 1 point 14 states that Early Childhood Education (PAUD), is a coaching effort aimed at children from birth to six years of age carried out by providing educational stimulation, to help with physical growth and development and spiritually in order to have the readiness to enter further education. Kindergarten (TK) as one of the formal education institutions strives to provide efforts to stimulate education to children by looking at various aspects of child development namely physical motor development, language development, cognitive development, social, emotional development, and religious and artistic moral development. At an early age, children have a strong sensitivity to everything around them in achieving their development. This sensitive period requires educators and teachers to optimize coaching and provision of education or stimulation on aspects of child development with materials that support their development.

One of the development areas taught in kindergarten is cognitive development that directs various abilities of children in solving problems in life, understanding, and knowing the concept of counting as a provision in the future. The concept of numeracy developed in kindergarten in the 4-5 year age group is adjusted to the Minister of National Education's Regulation on the standards of Early Childhood Education. It is namely the introduction of numeracy which includes: knowing the concept of many and few, knowing the concept of numbers, knowing the symbol of numbers, and getting to know the letter symbol and say a lot of things.

Reference [1] revealed that early age children aged 4-5 years were able to recognize and understood the concept of numbers and symbols by using concrete objects manipulated by the child's senses. Reference [2] reveals that counting is teaching to children in a pattern the empirical then presents the real objects continues to more methodical exercises that use the senses, so the child knows and remembers what he does. Children learn a new concept through interactions with the environment and testing or applying new concept [3]. This expression can be transformed that interaction with the environment around the child can provide new learning or new concepts for children in their learning experience. It is this interaction with the environment that can provide children's space to learn to count and understand the concept of numbers.

Based on the results of empirical observations at Kartika Wirabuana Kindergarten 51 , the ability to count children was very low. Children were still hesitant to distinguish numbers and symbols and were less able to recognize the concept of numbers, sort numbers $1-10$ by memorizing the numbers. The students did not know the number symbol correctly, for example, numbers 5 and 2 are often reversed called by children, 1 and 7 can not be distinguished many objects one to ten are still assisted by the teacher. The child pointed to the number but is not right to name the numbers. There was also one that is only silent when directed by the teachers relating to knowing the numbers and symbols.

In the development of cognitive aspects, especially in numeracy, teachers are less optimal and less varied in utilizing playing tools in the child's learning process. The activities carried out by the teacher on the cognitive aspects, especially counting, are done verbally and abstractly by using paper pencil tests. Children pointed to write letters 3, 2, 4 by the teacher and give color to letters or numbers, so that the concepts of counting in the form of recognition would be the concepts. Symbols and numbers are the lessons which are very slowly understood by children.

Early childhood who still have a low concentration level and are still in the preoperational stage and have egocentric 
nature require special handling especially in numeracy learning which is the basis of knowing the concepts of subsequent knowledge with fun activities supported by media or game tools simple and applicable and close to the child's environment.

There are other factors that influence the low numeracy ability of children. They are (1) the maturity of the child's mindset about numbers because the concept of abstract number delivery, the child is directed to know the numbers and symbols with unpleasant demonstrations; (2) The playing tools used are less attractive and not varied so that the child gets bored with the playing tools he uses; (3) Lack of communication between the teacher and parents as one of the means of teacher knowledge about the development of children's abilities; (4) The conventional learning approach that is teacher-centered and child-directed is to sit quietly and write, as well as coloring pictures; while parents only entrust their children's education to the teacher and (5) the skills and creativity of educators are less than optimal in providing stimulation. Based on the theories and empirical observation, the teacher should teach the counting by the concept, symbols, and concrete object. In this study, the researchers used the natural materials as the objects to teach counting.

Children are more interested in playing with natural materials that are outdoors such as leaves, stones, twigs, ajan but children who do not understand the natural material can develop their abilities, especially counting and other knowledge. The researchers hope that the use of the natural material in teaching counting could increase the children's counting ability.

\section{LITERATURE REVIEW}

\section{A. Natural Resources}

Reference [4] states that in and around the environment are created for humans. One of the benefits is as an excellent medium to teach many things to humans, especially for early childhood who are still experiencing development from all aspects. Efforts to utilize the natural surroundings in the context of education include knowledge about the way of work, conditions, impacts and the use of natural materials that are around as good materials and learning resources for children.

By utilizing natural materials, children will be interested in playing with their peers. Natural material media helps teachers/caregivers in providing stimulation concerning the concept of comparing, differentiating, classifying, etc. then can deduce their own knowledge based on the experience he has done by playing.

Sensory experiences using concrete materials around children in numeracy learning provide long-term memory in children about the knowledge that has been learned or done. From some of these exposures, the use of natural materials in the process of early childhood learning is very well used as a medium for early childhood learning.

\section{B. Implementation of Natural Materials to Improve Counting}

The natural ability materials used as media in the counting learning process are designed with attractive and fun colors for children. The natural materials used are as follows:

- Leaves: the leaves that are used as a medium to recognize numbers are orange leaves, banana leaves, and soursop leaves which are attached with number symbols 1-10. The banana leaves are designed and made to be a funny date. Counting activities with this media can help children recognize numbers, distinguish numbers, and sort numbers from small to the largest or vice versa. Meanwhile, the orange leaves and soursop leaves are designed to be number cards used to introduce numbers, distinguish numbers and sort numbers;

- Twigs: Branches are often designed with attractive colors made into door sticks used to introduce short, large, small lengths, sorting objects from the smallest to the biggest or the opposite, spelling many objects, recognizing their numbers and symbols, and

- Rocks: the stones used are selected from rocks that are clean and of various shapes and unique. These rocks are used as media to introduce children to many small concepts, the concept of classification of rock forms, differentiating types, numbering many objects.

To improve the numeracy skills of children aged 4-5 years, these natural materials are combined in their use in the study implementation cycle.

\section{METHOD}

The method used in this study was action research method with stages: 1) planning, 2) action, 3) observation, and 4) reflection. The subjects of this study were 15 students of grade A at Kartika Wirabuana 51 Kindergarten, Baubau. The data was collected by using field notes, documentation, and observation.

Numeracy ability of students was measured based on several indicators, namely the ability to understand the sequence of numbers, the number of objects, understanding more and fewer concepts, recognizing numbers and symbols, and understanding the concept of adding and subtracting objects or numbers with concrete objects. The instrument has been well designed, following the existing theories and conditions. Evaluation of the validity of the instruments prepared was conducted by 3 early childhood education experts so that the instruments used were said to be valid for use with children in group A. Measured using four choices of ability scores, namely: 1) able/independent (score 4); 2) quite capable/guided teachers (score 3 ); 3 ) bad/ guided by the teacher (score 2); not able (score 1).

\section{RESULTS AND Discussion}

The use of natural materials in learning calculation for kindergarten children is expected to improve students' numeracy skills. The results of students' numeracy skills were in the form of preliminary data. The achievements in cycles I and II can be seen in Table 1 . 
TABLE I. THE RESULTS OF STUDENTS' NUMERACY SKILLS

\begin{tabular}{|l|c|c|c|c|c|l|}
\hline \multirow{2}{*}{ Student } & \multicolumn{2}{|c|}{$\begin{array}{c}\text { Preliminary } \\
\text { data }\end{array}$} & \multicolumn{2}{c|}{ Cycle I } & \multicolumn{2}{c|}{ Cycle II } \\
\cline { 2 - 7 } & Score & (\%) & Score & $(\%)$ & Score & (\%) \\
\hline 1 & 36.00 & 45.00 & 61.00 & 76.25 & 75.00 & 93.75 \\
\hline 2 & 43.00 & 53.75 & 70.00 & 87.50 & 78.00 & 97.50 \\
\hline 3 & 28.00 & 35.00 & 49.00 & 61.25 & 60.00 & 75.00 \\
\hline 4 & 28.00 & 35.00 & 54.00 & 67.50 & 67.00 & 83.75 \\
\hline 5 & 44.00 & 55.00 & 68.00 & 85.00 & 78.00 & 97.5 \\
\hline 6 & 33.00 & 41.25 & 58.00 & 72.50 & 69.00 & 86.25 \\
\hline 7 & 37.00 & 46.25 & 60.00 & 75.00 & 78.00 & 97.5 \\
\hline 8 & 23.00 & 28.75 & 45.00 & 56.25 & 56.00 & 70.00 \\
\hline 9 & 40.00 & 50.00 & 58.00 & 72.50 & 71.00 & 88.75 \\
\hline 10 & 46.00 & 57.50 & 72.00 & 90.00 & 78.00 & 97.50 \\
\hline 11 & 38.00 & 47.50 & 58.00 & 72.50 & 74.00 & 92.50 \\
\hline 12 & 50.00 & 62.50 & 76.00 & 95.00 & 80.00 & 100.00 \\
\hline 13 & 36.00 & 45.00 & 62.00 & 77.50 & 76.00 & 95.00 \\
\hline 14 & 32.00 & 40.00 & 60.00 & 75.00 & 72.00 & 90.00 \\
\hline 15 & 36.00 & 45.00 & 65.00 & 81.25 & 78.00 & 97.50 \\
\hline Average & 36,67 & 45.83 & 61.07 & 76.33 & 72.67 & 90.83 \\
\hline
\end{tabular}

Table I shows that the ability to count of the children in group A by utilizing natural ingredients increases every cycle. The indicator of numeracy consisting of the numbers of objects, the number of objects, understanding numbers, symbols, and the concept of adding and subtracting objects or numbers with concrete objects are in a developing and consistent stage.

Based on the results of this study, there is an increase in the childrens' counting ability by using natural materials. The children feel easy to apply the objects in learning to count. In the process of learning, the children used the leaves, rocks, and branches as the objects to count. Children also learn the corresponding number. It matched the numbers symbols with the objects, and classification. The children grouped objects by a common attribute or characteristic such as size, shape, and colour. They put the objects in order based on the ability to place them in logical sequence suche as smallest to largest, short to long. They also learned the number operation with used the leaves, rocks, and branches. Reference [5] stated that abilities include learning achievement, intelligence, and talent. Reference [6] says that ability as learning outcomes comes in five categories, namely, (1) intellectual skills, (2) verbal information, (3) cognitive strategies, (4) motoric skills, and (5) attitude. Based on the opinions of the experts above, it can be concluded that ability is a power to perform certain actions as a result of repeated learning and practice.

Counting written by reference [7] is one of the components of mathematics that develops numerical language/symbols that allow individuals to make quantitative measurements. Early childhood is an individual who is in a sensitive period need to be given initial stimulation related to counting for provision in the next life. Reference [8] said that "count real things to help children use their own experiences with objects to understand numbers better". Can be interpreted to count with real objects help children use their own experience and given certain objects children better understand numbers. Reference [1] added that "Counting is learned for the most part through naturalistic and informal supported by structured activities lesson".
As for activities-counting activities according to Charleswoth in reference [9] include activities of comparing, classifying, measuring, experimenting, observing, and exploring to foster an understanding of the concept of numeracy itself. Reference [10] reveals counting in Kindergarten is an introduction to the meaning and concept of numbers whose use is adapted to age and children's education. Reference [10] found that children aged 4-5 years can count to five. Reference[11] writes that children's basic numeracy skills include understanding the concept of numbers and remembering the sequence of numbers.

Reference [12] said that "counting is an understanding of number, operation of numbers, functions, and relations, probability and measurement". This statement could mean that counting is an understanding of numbers, number operations, functions and numbers, capabilities and measurements. From the explanation above, it can be concluded that Kindergartenage children can already be introduced to numeracy, which includes number recognition and number concepts, distinguishing the terms "many and few" by sorting numbers with concrete media.

\section{CONCLUSION}

The use of natural materials in kindergarten learning can improve students' numeracy skills. Natural materials in the form of leaves, stones, and twigs that are affixed with numbers can be used and developed by the teacher with a more varied and fun playing model so that it can help children improve numeracy skills according to the stage of development. Therefore, teachers, parents, and school administrators further enhance their knowledge of early childhood to provide better care and motivation for children in the future.

\section{REFERENCES}

[1] R. Charlesworth, Experience In Math for Young Childeren, New York: Delmar publishers, 2005.

[2] M. Montessori, Metode Montessori terjemahan Ahmad Lintang Lazuardi, Yogyakarta: Pustaka Pelajar, 2013

[3] J. Catron and Allen, Early childhood curriculum A Creative-Play Model, London: Prentice Hall, 1999.

[4] I. Musbikin, Buku Pintar PAUD” dalam perspektif islam, Yogyakarta: Laksana, 2010.

[5] H, Djaali, Psikologi Pendidikan, Jakarta: Bumi Aksara, 2013.

[6] D. R. Ekawarna, Penelitian Tindakan Kelas, Jambi: Gaung Persada, 2011.

[7] J. S. Suriasumantri, Ilmu dalam Perspektif sebuah kumpulan karangan tentang hakekat ilmu, Jakarta: Yayasan Obor Indonesia, 2007.

[8] H. Jackman, Early Education Curriculum A Child's connection to the Word. Belmont, USA: Delmar Cengage Learning, 2009

[9] M. Kostelnik, et al., Developmentally Appropriate Curriculum Best Practice in Early Childhood Education, Columbus, Ohio: Pearson, Merril Prentic Hall, 2007.

[10] E. B. Hurlock, Perkembangan Anak jilid 2, Jakarta: Erlangga, 2010.

[11] M. Jamaris, Kesulitan Belajar perspektif, assessment, dan penanggualanganya, Jakarta: Yayasan Penamas Murni, 2009.

[12] J. A. Brewer, Introduction to Early Childhood Education Preschool through Primary Grades, Boston : Pearson Education, 2007 